\section{Merdas Al-Otibi, M.D. \\ Division of Neurosurgery, Department of Surgery, \\ Hospital for Sick Children, \\ University of Toronto Faculty of Medicine, \\ Toronto, Canada}

James T. Rutka, M.D., Ph.D.

Division of Neurosurgery,

Department of Surgery,

Hospital for Sick Children,

University of Toronto Faculty of Medicine,

Toronto, Canada

James M. Drake, M.B., M.Sc.

Division of Neurosurgery,

Department of Surgery,

Hospital for Sick Children,

University of Toronto Faculty of Medicine,

Toronto, Canada

Peter B. Dirks, M.D., Ph.D.

Division of Neurosurgery,

Department of Surgery,

Hospital for Sick Children,

University of Toronto Faculty of Medicine,

Toronto, Canada

Abhaya V. Kulkarni, M.D., Ph.D.

Division of Neurosurgery,

Department of Surgery,

Hospital for Sick Children,

University of Toronto Faculty of Medicine,

Toronto, Canada

Michael D. Taylor, M.D., Ph.D.

Division of Neurosurgery,

Department of Surgery,

Hospital for Sick Children,

University of Toronto Faculty of Medicine,

Toronto, Canada

\section{Robin P. Humphreys, M.D.}

Division of Neurosurgery,

Department of Surgery,

Hospital for Sick Children,

University of Toronto Faculty of Medicine,

Toronto, Canada

\section{Reprint requests:}

Robin P. Humphreys, M.D.,

Division of Neurosurgery,

Hospital for Sick Children,

555 University Avenue, Suite 1503,

Toronto, Ontario, Canada M5G 1 X8.

Email: cnsurg@sickkids.ca

Received, January 13, 2007.

Accepted, April 12, 2007

\title{
The History of Neurosurgery at the Hospital FOR SiCK CHILDREN IN TORONTO
}

THE TRADITION OF selfless charity for children in Toronto was established by Elizabeth McMaster, founder of the Hospital for Sick Children, or "Sick Kids," in 1875. The tradition of fortitude and perseverance in trying to cure children who were deemed incurable by others was sealed into the history of the Hospital by early pioneering surgeons, including Drs. Clarence Starr, A.W. Farmer, and William Gallie. Dr. William Gallie recognized the importance of neurosurgery for the future of the Hospital and encouraged Dr. William Keith to acquire training in pediatric neurosurgery in Chicago and London. Dr. Keith began the practice of pediatric neurosurgery at Sick Kids in 1935 and worked in the primordial phase of the subspecialty for the next 20 years until he was joined by Dr. E. Bruce Hendrick in 1955. In time, Dr. Hendrick was joined by Drs. Harold Hoffman and Robin Humphreys who led a decidedly strong pediatric neurosurgery unit between 1975 and 1995. During this epoch, the pediatric neurosurgery service grew to become one of the busiest and most progressive units in the world. Over the years, numerous neurosurgery fellows and faculty from all over the world have trained at or have visited Sick Kids to learn how pediatric neurosurgery is practiced in Toronto. The purpose of this article is to review the history of the individuals who founded the Hospital for Sick Children and its Division of Neurosurgery.

KEY WORDS: Hospital for Sick Children, Medical history, Neurosurgery, Pediatric neurosurgery

Neurosurgery 61:612-625, 2007

DOI: 10.1227/01.NEU.0000280036.24663.EA

www.neurosurgery-online.com

$\mathbf{T}$ he pediatric neurosurgery service at the Hospital for Sick Children ("Sick Kids") has had a rich tradition of excellence devoted to children with neurosurgical disorders. Although the first neurosurgeon to perform surgery at Sick Kids was Dr. William Keith in 1933, it was not until the arrival of Dr. E. Bruce Hendrick, Canada's first fully trained pediatric neurosurgeon, who had trained under Dr. Donald Matson in 1952, that a fulltime pediatric neurosurgeon was devoted to the care of children. Dr. Hendrick was subsequently joined by Dr. Harold Hoffman in the 1960s and Dr. Robin Humphreys in the 1970s at a time when pediatric neurosurgery was developing as a bona fide subspecialty in neurosurgery. Other centers that were developing pediatric neurosurgery services at this time were located in Boston, Chicago, Philadelphia, and New York.

The following is an account of the history of the Hospital for Sick Children, a haven where pediatric neurosurgery has grown and flour- ished and where numerous fellows and faculty from all corners of the globe have come to seek specialty training in the field.

\section{ELIZABETH MCMASTER AND MAGGIE: THE HISTORY OF THE HOSPITAL FOR SICK CHILDREN}

Elizabeth Janet Wyllie, the daughter of Scottish immigrants, George Black Wyllie and Mary Ann Reid, was born on December 27, 1847, in Toronto. She married Samuel Fenton McMaster on June 1, 1865, when she was not yet 18 years of age. Samuel F. McMaster was a successful businessman in the dry goods importing industry. He was the nephew of Senator William McMaster, founder of McMaster University in Hamilton, Ontario. By 1874, Elizabeth McMaster had already borne three children.

During that time, the population of the city of Toronto was 68,000. For the most part, it was a wealthy, bustling city enjoying its eighth year 
as the capital of Ontario. However, the streets were also filled with Torontonians who were desperately poor. There were no welfare, family allowance, health plan, unemployment insurance, or pension plans to help them. Children suffered the most, coughing from bronchopneumonia; hobbling from tuberculosis osteomyelitis; and dying from diphtheria, scarlet fever, typhoid fever, and septicemia (4). Elizabeth McMaster believed that general hospitals did not provide the special care children needed (4). Childrens' hospitals had already been established in 17 major European cities, but the only childrens' hospital in the British Empire was at Great Ormond Street

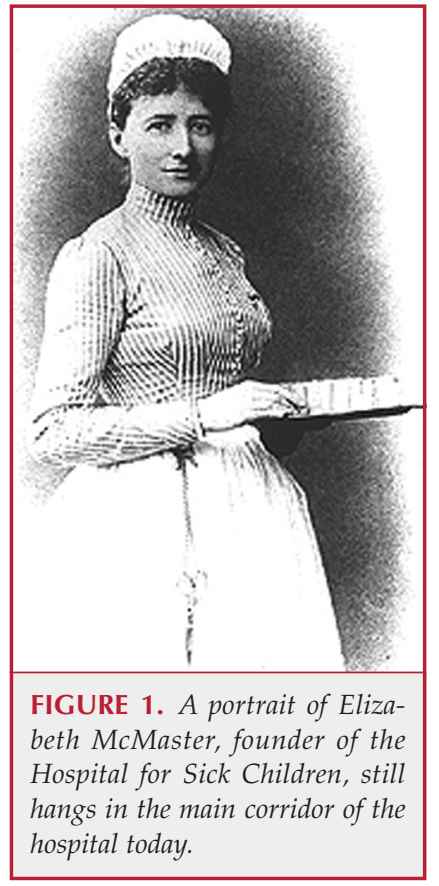
in London. Elizabeth McMaster was determined to establish the second one in Toronto (Fig. 1) (4).

In 1874, a group of deeply religious women who possessed a strong social conscience and cared a great deal for the condition of the poor met in the home of Mrs. Elizabeth McMaster to consider how they could help sick children. They decided to establish a hospital to help the poor and sick children of Toronto. The hospital they founded was opened on March 1, 1875. The group of women rented an 11-room house in downtown Toronto, where the Toronto General Hospital now stands, for $\$ 320$ a year. There, they set up six iron cots and declared the hospital open "for the admission and treatment of all sick children" (4). One month later, on April 3, 1875, Maggie, a victim of a scalding burn, became the first patient of the Hospital for Sick Children in Toronto.

The first Annual Report of the Hospital (4), dated July 1, 1876, stated that in the first year, the Hospital treated 111 patients. Forty-four children were inpatients; 67 were treated as outpatients. Of the inpatients, 21 were surgical patients and 23 were medical patients. Interestingly, this ratio between surgical and medical patients seen in the Hospital has been maintained to the present time (17).

The demand for services was so great that the hospital had to move to a larger building in 1876, another rented house at 206 Seaton Street. This house could accommodate 16 patients at one time. In 1891, under the leadership of John Ross Robertson, publisher of the Evening Telegram and chairman of the Hospital's Board of Trustees, the Hospital for Sick Children moved to a new four-story, 320-bed facility at the corner of Elizabeth and College Streets (Fig. 2). The Toronto city council asked that it be named "Victoria Hospital for Sick Children," but the new name was never officially
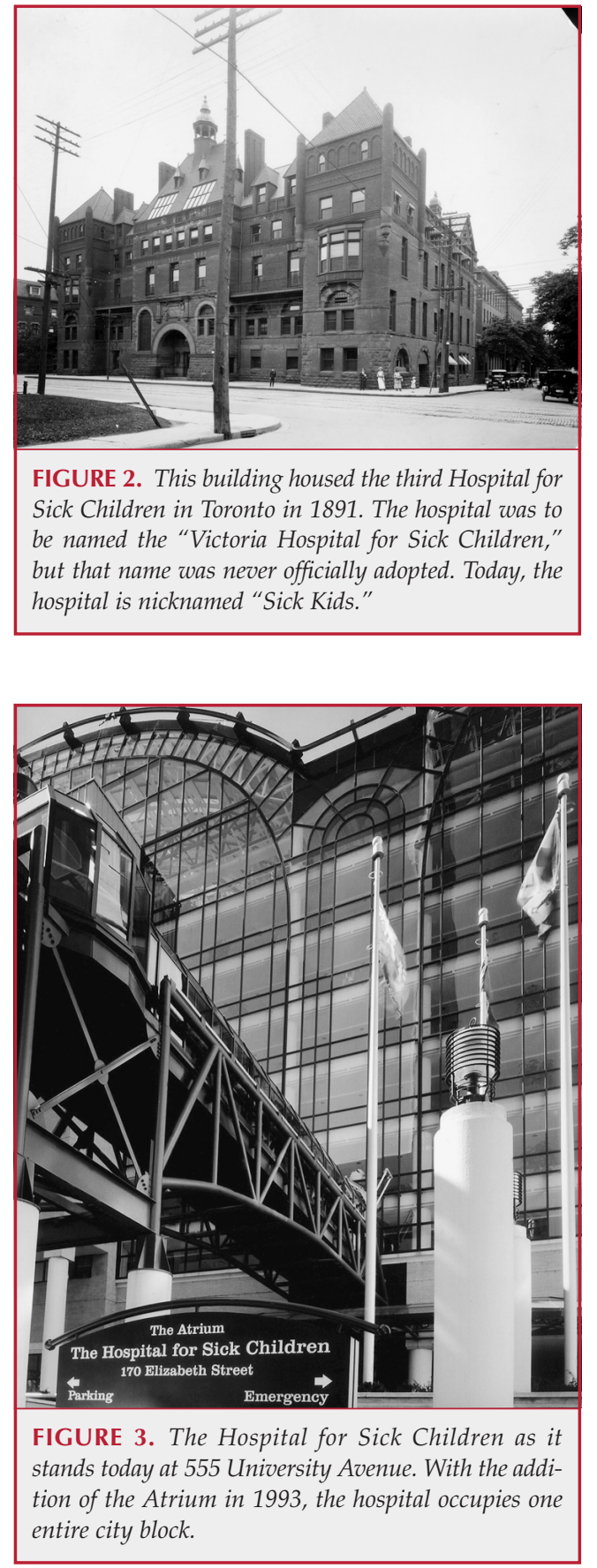

adopted. Instead, the Hospital for Sick Children became known as "Sick Kids."

On February 4, 1951, the hospital moved to its current location at 555 University Avenue (Fig. 3), occupying the grounds where the childhood home of actress Mary Pickford once stood. At the same time, there was a switch in emphasis from nutritional research to the repair of congenital defects. Three years later, the Research Institute was established. 


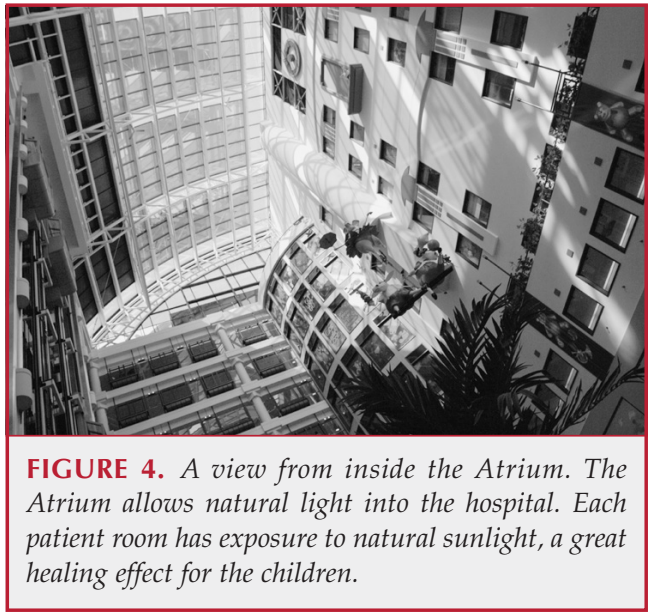

In January 1993, a new inpatient facility was built, complete with an expansive Atrium just behind the 555 University Avenue site (Fig. 4). The Atrium was designed by Eberhard Zeidler of the Zeidler-Roberts Partnership. Believing that light is important to healing, Zeidler designed the building around a nine-story, glass-roofed atrium. Most patients now have their own room with natural sunlight, a washroom, storage, and a day bed so that a parent can stay overnight. With the addition of the new wing, the hospital now occupies an entire city block. The Atrium houses facilities to help provide enhanced care and improve the treatment and diagnosis of childhood disease. The critical care unit, where children with life-threatening illness and injury receive care, almost doubled in size to 36 beds. The emergency department has two trauma rooms and a six-bed observation room. The operating room now houses 15 operating rooms, each fully equipped to perform modern surgical practices across six different divisions. Most recently, on May 25, 2001, the imaging guided therapy department opened, enabling surgeons to perform interventional radiological and minimally invasive neurosurgical procedures under image guidance.

\section{THE KEITH YEARS: THE BIRTH OF THE DIVISION OF NEUROSURGERY}

Dr. William S. Keith, the second of four children, was born in Toronto on June 20,1902. He was educated in Toronto and completed medical school at the University of Toronto in 1927. After graduation, he performed his internship at the Toronto General Hospital and had the opportunity to work with Dr. Kenneth McKenzie, Canada's first neurosurgeon $(1,69)$. It was this early experience working with Dr. McKenzie that inspired Dr. Keith to pursue a career in neurosurgery $(12,13,26)$.

In 1929, Dr. Gallie, Surgeon-in-Chief at the Hospital for Sick Children, encouraged Dr. Keith to become a neurosurgeon and to work at the Hospital for Sick Children (14). He secured a Douglas Smith Fellowship for Dr. Keith, which allowed him to study at the University of Chicago with Dr. Roy Grinker, Professor of Neurology, and Dr. Percival Bailey, Professor of
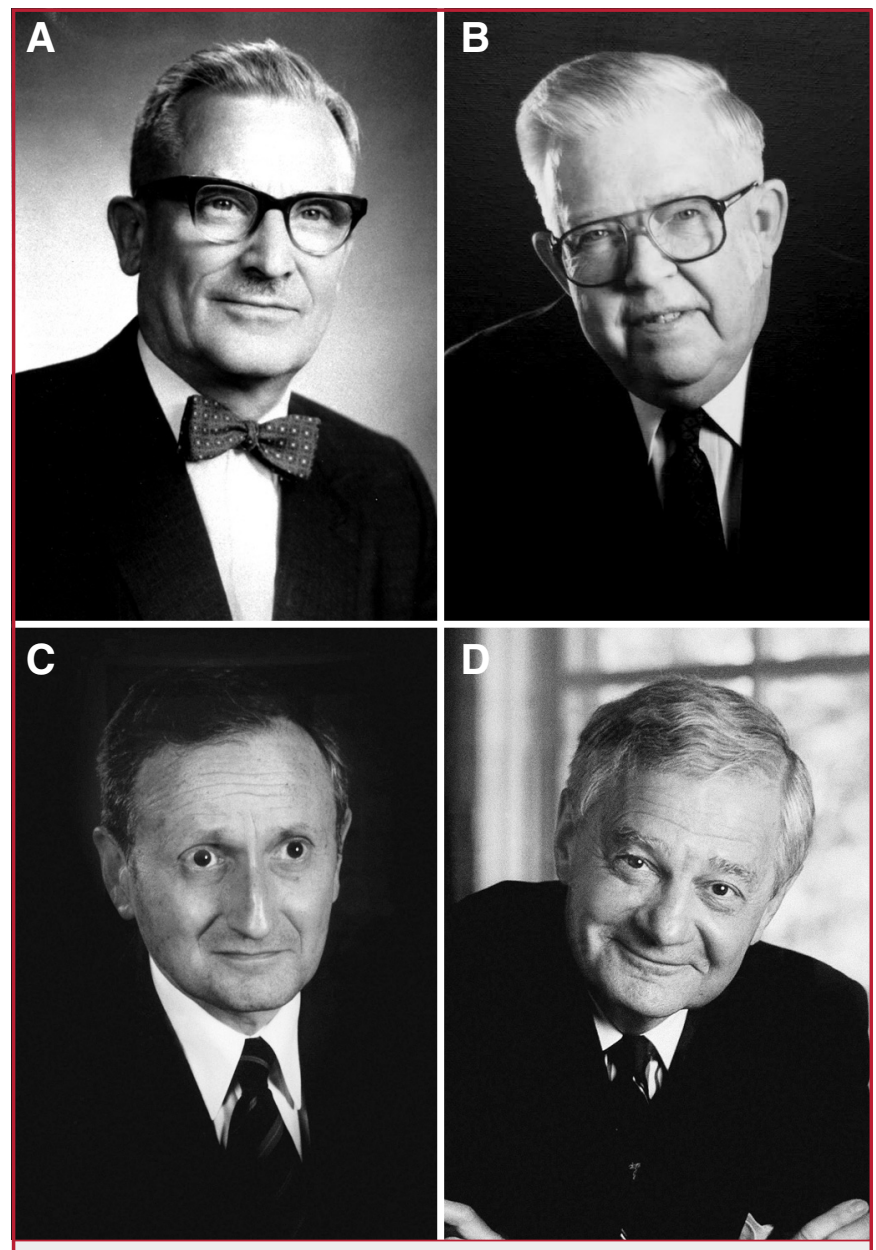

FIGURE 5. Portraits of the fathers of neurosurgery at the Hospital for Sick Children: Dr. William Keith (A), Dr. E. Bruce Hendrick (B), Dr. Harold Hoffman (C), and Dr. Robin Humphreys (D).

Neurosurgery (26). Dr. Keith also had an opportunity to work with Dr. Paul Bucy who was finishing his residency as Dr. Bailey's Chief Resident.

Dr. Keith returned to Toronto in 1930 to work with Dr. McKenzie $(1,12,13,69)$. One year later, in 1931, the Hospital for Sick Children sponsored his studies at the National Hospital for Neurological Disorders at Queen's Square in London, England, as a Clinical Clerk to the Neurology Service (26). While in England, on April 2, 1931, he married Eleanor, a nurse who worked at the Hospital for Sick Children in Toronto.

He returned to the Hospital for Sick Children to become Chief Resident in Surgery. In 1933, he joined the staff at the Hospital for Sick Children with a primary interest in neurosurgery. At the time, neurosurgery was a fledgling specialty, and Dr. Keith was required to take call for general surgery and orthopedic surgery (14). In 1936, he organized an adult neurosurgical service at the Toronto Western Hospital. He continued to serve as Chief of Neurosurgery at both the Hospital for Sick Children and the Toronto Western Hospital until his retirement in 1964 (Fig. 5A). 
TABLE 1. Major contributions to neurosurgery and Pediatric neurosurgery by Dr. William S. Keith and the " $3 \mathrm{Hs}^{\text {" }}$

\begin{tabular}{|c|c|c|}
\hline Subspecialty & Contribution & References \\
\hline \multirow[t]{6}{*}{ Hydrocephalus } & Management of shunt infections & 93 \\
\hline & $\begin{array}{l}\text { Experience with ventriculopleural } \\
\text { shunts }\end{array}$ & 39 \\
\hline & $\begin{array}{l}\text { Lumboperitoneal shunt for } \\
\text { hydrocephalus }\end{array}$ & 37 \\
\hline & Percutaneous third ventriculostomy & 31 \\
\hline & Slit ventricle syndrome & 50 \\
\hline & Normal pressure hydrocephalus & 61 \\
\hline \multirow[t]{4}{*}{ Epilepsy } & Lesional temporal lobe epilepsy & 9 \\
\hline & Rasmussen's encephalitis & 77 \\
\hline & Hemispherectomy & 23,33 \\
\hline & Posttraumatic epilepsy & 21 \\
\hline \multirow[t]{5}{*}{ Cerebrovascular } & Moyamoya disease & 28 \\
\hline & $\begin{array}{l}\text { Management of arteriovenous } \\
\text { malformations }\end{array}$ & $57,60,63$ \\
\hline & Pediatric hemorrhagic strokes & 52 \\
\hline & Vein of Galen malformations & 29 \\
\hline & Pediatric intracranial aneurysms & 88 \\
\hline \multirow[t]{12}{*}{ Neuro-oncology } & Craniopharyngiomas & $30,42,59$ \\
\hline & Gangliogliomas & 15,72 \\
\hline & Low-grade astrocytomas & 47 \\
\hline & Optic pathway/hypothalamic gliomas & 43 \\
\hline & Dorsally exophytic brainstem gliomas & $78,89,90$ \\
\hline & Intracranial germ cell tumors & 46 \\
\hline & Infratentorial ependymomas & 71 \\
\hline & Thalamic tumors & 3 \\
\hline & Congenital neoplasms & 2 \\
\hline & Medulloblastoma & $36,40,76$ \\
\hline & Pineal region tumors & 49 \\
\hline & Tectal gliomas & 67 \\
\hline \multirow[t]{6}{*}{ Spine } & Tethered cord syndrome & 24,38 \\
\hline & Lumbar disc disease in children & 16 \\
\hline & Hydrosyringomyelia & 45 \\
\hline & Traumatic spinal cord infarction & 5,61 \\
\hline & Whiplash injury & 62 \\
\hline & Occipital neuralgia & 62 \\
\hline Congenital & Separation of craniopagus twins & 83 \\
\hline abnormalities & Encephaloceles & 66 \\
\hline \multirow[t]{6}{*}{ of development } & Colloid cysts & 65 \\
\hline & Lipomyelomeningoceles & 48 \\
\hline & $\begin{array}{l}\text { Surgical management of Chiari I } \\
\text { malformations }\end{array}$ & 35,75 \\
\hline & $\begin{array}{l}\text { Surgical management of Chiari II } \\
\text { malformations }\end{array}$ & 92 \\
\hline & Dermoid cysts of the anterior fontanelle & 74 \\
\hline & Suprasellar arachnoid cysts & 41 \\
\hline \multirow[t]{3}{*}{ Neurotrauma } & $\begin{array}{l}\text { Complications of pediatric head } \\
\text { trauma }\end{array}$ & $22,53,58$ \\
\hline & Significance of skull fractures & 18 \\
\hline & $\begin{array}{l}\text { Therapeutic benefit of hypothermia in } \\
\text { severe head trauma }\end{array}$ & 19 \\
\hline Craniofacial & Lambdoid synostosis & 70 \\
\hline \multirow[t]{2}{*}{ abnormalities } & $\begin{array}{l}\text { Early repair of craniofacial } \\
\text { dysmorphism }\end{array}$ & 32 \\
\hline & $\begin{array}{l}\text { Management of unilateral and } \\
\text { bilateral coronal craniosynostosis }\end{array}$ & 44,68 \\
\hline \multirow[t]{2}{*}{ Infection } & $\begin{array}{l}\text { Subdural empyema and epidural } \\
\text { abscess }\end{array}$ & 87 \\
\hline & Cerebral abscesses in infants & 34 \\
\hline Surgical technology & Frameless stereotaxy & $11,25,73$ \\
\hline
\end{tabular}

In May 1942, Dr. Keith volunteered to serve in the Canadian Armed Forces and organized a mobile neurosurgical unit. He returned to Toronto in May 1945 to resume his neurosurgical practice and his duties at the University of Toronto. He was a founding member of the Canadian Neurological Society and served as President from 1964 to 1965.

At the Hospital for Sick Children, he pioneered pediatric neurosurgery (Table 1). He was one of the early proponents of lumboperitoneal shunting for hydrocephalus, which he introduced to the Hospital for Sick Children in 1948. During these early years of pediatric neurosurgery in Toronto, Dr. Keith developed significant experience treating children with head trauma, craniofacial disorders, spina bifida, hydrocephalus, and stroke. He trained many young, aspiring pediatric neurosurgeons, including Dr. Harold J. Hoffman (26).

For almost 20 years, Dr. Keith maintained a hurried pace as the sole neurosurgeon for both the Hospital for Sick Children and the Toronto Western Hospital. He was joined by Dr. Ross Fleming at the Toronto Western Hospital and by Dr. E. Bruce Hendrick at the Hospital for Sick Children in 1954 and 1955, respectively.

Dr. Keith had a long-term friendship with Dr. Frank Mayfield, dating back to 1938, and the two were among several neurosurgeons who founded the American Academy of Neurological Surgery (26).

In 1964, he retired from the University of Toronto staff and from his position as Chief of Neurosurgery at both the Toronto Western Hospital and the Hospital for Sick Children. Dr. Keith continued general practice in aboriginal communities in Ontario, British Columbia, and Newfoundland, and as a camp doctor in northern Ontario for children with medical disorders (14) for many years. On December 27, 1987, at the age of 85, Dr. Keith died of Hodgkin's disease at his home in Toronto surrounded by his family. In his name, the annual William Keith Lectureship has been established at the Toronto Western Hospital in the Division of Neurosurgery. A listing of past Keith Visiting Professors in Toronto is shown in Table 2.

\section{HISTORY IN THE MAKING: THE ERA OF "THE 3 H's"}

\section{E. Bruce Hendrick}

Dr. E. Bruce Hendrick, a native Torontonian who was born, lived, practiced, retired, and died in the city (27). Apart from a brief absence during his residency, his unflagging loyalty to Canada had been sustained through his high school and University of Toronto education, the postgraduate surgical training (the famed Gallie Course) at that university, and a brief military career. He traveled to Boston in 1952 to begin a 2-year fellowship at the Children's Hospital and Peter Bent Brigham Hospital, where he studied under Drs. Franc Ingraham and Donald Matson.

The Hendrick aphorisms, of which there are many, such as the time he asked Dr. Matson's patient with a spinal cord tumor 


\begin{tabular}{|c|c|c|}
\hline Year & Lecturer & City of residence \\
\hline 1976 & Prof. Gilles Bertrand & Montreal, Canada \\
\hline 1977 & Prof. Douglas Miller & Edinburgh, Scotland \\
\hline 1978 & Dr. Robert Ojemann & Boston, MA \\
\hline 1979 & Prof. Bryce K.A. Weir & Edmonton, Canada \\
\hline 1980 & Prof. Lindsay Symon & London, England \\
\hline 1981 & Dr. Blaine Nashold & Durham, NC \\
\hline 1982 & Prof. Charles Drake & London, Canada \\
\hline 1983 & Prof. Graham Teasdale & Glasgow, Scotland \\
\hline 1984 & Dr. Douglas Long & Baltimore, MD \\
\hline 1985 & Prof. Patrick Derome & Paris, France \\
\hline 1986 & Dr. Charles Wilson & San Francisco, CA \\
\hline 1987 & Prof. Kenichiro Sugita & Matsumoto, Japan \\
\hline 1988 & Prof. Madjid Samii & Hannover, Germany \\
\hline 1989 & Dr. Toralf M. Sundt & Rochester, MN \\
\hline 1990 & Prof. Tyrone Hardy & Montreal, Canada \\
\hline 1991 & Dr. George Ojemann & Seattle, WA \\
\hline 1992 & Dr. Laligam N. Sekhar & Pittsburgh, PA \\
\hline 1993 & Prof. Andrè Olivier & Montreal, Canada \\
\hline 1994 & Dr. Robert Martuza & Washington, D.C. \\
\hline 1995 & Dr. Volker K.H. Sonntag & Phoenix, AZ \\
\hline 1996 & Dr. Roberto C. Heros & Miami, FL \\
\hline 1997 & Prof. Alim-Louis Benabid & Grenoble, France \\
\hline 1999 & Dr. Edward Oldfield & Bethesda, MD \\
\hline 2000 & Dr. Arnold Menezes & lowa City, IA \\
\hline 2001 & Dr. David Piepgras & Rochester, MN \\
\hline 2002 & Dr. Mitchel Berger & San Francisco, CA \\
\hline 2003 & Dr. Edward Benzel & Cleveland, $\mathrm{OH}$ \\
\hline 2004 & Dr. David Roberts & Lebanon, $\mathrm{NH}$ \\
\hline 2005 & Dr. Richard Fessler & Chicago, IL \\
\hline 2006 & Dr. Webster H. Pilcher & Rochester, NY \\
\hline
\end{tabular}

and associated paresthesias if "[his] legs feel like ginger ale looks" (55, p 100) will remain with students and residents alike for generations to come.

Having completed his training in pediatric neurosurgery in Boston, Dr. Hendrick returned to Toronto in 1954 to begin neurosurgical practice at the Hospital for Sick Children. Although he also held responsibilities at the Toronto Western Hospital, his joy came from caring for children with neurosurgical disorders. Dr. Hendrick became Neurosurgeon-in-Chief at the Hospital for Sick Children in 1964 (Fig. 5B).

Dr. Derek Harwood-Nash, a young South African newly graduated from medical school, obtained a neurosurgical fellowship at the Hospital for Sick Children to work on a pediatric head injury project under the mentorship of Dr. Hendrick (51). From that time, he remained in Canada to complete a residency in radiology at the University of Toronto and, after a fellowship, he joined the Sick Kids staff and dedicated himself to the emerging specialty of pediatric neuroradiology. After morning sessions performing ventriculograms, myelograms, and arteriography, Dr. Harwood-Nash would hold court in his tiny office cluttered with viewing boxes and bags of films. Without the benefit of modern neuroimaging techniques, he had to interpret inferential data, such as obscured air shadows and suspended droplets of contrast, and provide a learned opinion on the structural disorder in the child's nervous system. Eventually, he championed the Hospital for Sick Children's acquisition of computed tomographic and magnetic resonance imaging scanners, which are now ubiquitous in all pediatric hospitals. He was responsible for the training of more than 70 fellows in pediatric neuroradiology, many of whom were internationals $(6,51)$. Dr. Harwood-Nash, regarded by some as the "4th $\mathrm{H}^{\text {" in }}$

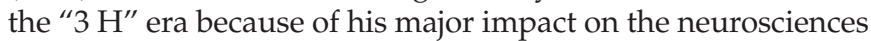
at the time, died suddenly and unexpectedly from a basilar artery dissection on October 18, $1996(6,51)$.

Over the years, the relationship between Dr. Hendrick and his resident staff evolved into something truly unique. Eschewing complete reliance on gadgetry for clinical decisions, he taught residents to adhere to fundamental Oslerian principles of history gathering and physical examination or, as he said in a 1993 editorial, "Whatever mother says!" (20, p 193). He advised residents to be prepared to defend their own conclusions and not to be influenced by the "reckless courage of the noncombatant" (55).

Dr. Hendrick had been part of the nascence and maturation of the specialty of pediatric neurosurgery (Table 1) (80). He was on the founding committees of the International Society of Pediatric Neurosurgery and the American Society of Pediatric Neurosurgeons. He was President of the Canadian Neurosurgical Society and was a Board Member of the American Association of Neurological Surgeons, which honored him in 1998 as the first recipient of the Franc D. Ingraham Lifetime Achievement Award.

Dr. Hendrick's most enduring contribution to pediatric neurosurgery was his devotion to his patients (27). He brought joy to the children for whom he cared. In return, they showered him with crayon drawings, stuffed toys, small soldiers, and large cigars. The Friday afternoon water gun fights (55) were serious business. Nurses, parents, and child life therapists joined patients to develop strategies on how to outdo "Uncle Bruce" in the water gun fights. Syringe barrels worked for patients who did not have their own water pistols. The children wore green garbage bags while Uncle Bruce took the soaking in his scrub suit.

A familiar sight late at night in the Hospital would be Dr. Hendrick sitting in his office with arms folded across numerous open books on his desktop, providing fatherly counsel to young parents seeking hope and reassurance concerning their child's illness. Occasionally, at times when he had to disappoint and break bad news to parents, Dr. Hendrick, in expressing his own frustration, could be heard saying, "If I had distilled essence of moonbeams to give, I would" (55, p 101). 
TABLE 3. Past E. Bruce Hendrick professors of pediatric neurosurgery

\begin{tabular}{|c|c|c|}
\hline Year & Visiting professor & Institution \\
\hline 1986 & Dr. Fred J. Epstein & New York University, New York, New York \\
\hline 1987 & Dr. Luis Schut & University of Pennsylvania, Philadelphia, Pennsylvania \\
\hline 1988 & Dr. Marion L. Walker & University of Utah, Salt Lake City, Utah \\
\hline 1989 & Professor Maurice Choux & I'Hôpital des Enfants de la Timone, Marseille, France \\
\hline 1990 & Dr. Michael S.B. Edwards & University of California San Francisco, San Francisco, California \\
\hline 1991 & Dr. David G. McLone & Northwestern University, Chicago, Illinois \\
\hline 1992 & Dr. R. Michael Scott & Harvard University, Boston, Massachusetts \\
\hline 1993 & Professor Kiyoshi Sato & Juntendo University School of Medicine, Tokyo, Japan \\
\hline 1994 & Dr. Warwick J. Peacock & University of California Los Angeles, Los Angeles, California \\
\hline 1995 & Dr. J. Gordon McComb & University of Southern California, Los Angeles, California \\
\hline 1996 & Professor Christian Sainte-Rose & University of Paris, Paris, France \\
\hline 1997 & Dr. Derek A. Bruce & University of Texas Southwestern Medical Center, Dallas, Texas \\
\hline 1998 & Professor Concezio Di Rocco & Catolica University Medical School, Rome, Italy \\
\hline 1999 & Dr. Harold L. Rekate & University of Arizona School of Medicine, Phoenix, Arizona \\
\hline 2000 & Dr. Tae Sung Park & Washington University, St. Louis, Missouri \\
\hline 2001 & Professor D. Douglas Cochrane & University of British Columbia, Vancouver, British Columbia, Canada \\
\hline 2002 & Professor Dominique Renier & University of Paris, Paris, France \\
\hline 2003 & Professor Anthony D. Hockley & Diana, Princess of Wales Children's Hospital, Birmingham, UK \\
\hline 2004 & Dr. W. Jerry Oakes & University of Alabama, Birmingham, Alabama \\
\hline 2005 & Professor Alain Pierre-Khan & I'Hôpital Necker-Enfants Malades, Paris, France \\
\hline 2006 & Dr. Robert A. Sanford & St. Jude Children's Research Hospital, Memphis, Tennessee \\
\hline
\end{tabular}

Throughout his professional career, Dr. Hendrick enjoyed the tremendous support of his wife, Gloria, to whom he had been married for 54 years, and his children, Michael and Sheelagh, who he described as always being there for him (55). Sadly, Dr. Hendrick died in 2001 from complications related to ruptured diverticulitis. The annual E. Bruce Hendrick Lectureship has been established in his honor at the Hospital for Sick Children in the Division of Neurosurgery. A listing of past Hendrick Lecturers at Sick Kids is shown in Table 3.

\section{Harold J. Hoffman}

Dr. Harold J. Hoffman was arguably the most famous pediatric neurosurgeon of his day (82). He set the standard for the treatment of many pediatric neurosurgical disorders by virtue of his understanding of the diseases that afflicted children, his unparalleled surgical skills, and his numerous publications in the scientific literature.

Dr. Hoffman graduated from the University of Toronto Faculty of Medicine in 1956. In 1957, he married JoAnn Shulman and became the loving father of Richard, Andrew, and Katie soon thereafter (82). Dr. Hoffman traveled to London in 1963 to complete a McLaughlin Fellowship before returning to Toronto.

He joined the Neurosurgical Staff at the Hospital for Sick Children in 1964. At that time, the neurosurgeon's day was occupied with the management and treatment of head trauma and brain tumors. Therefore, the major focus of Dr. Hoffman's practice was the treatment of pediatric brain tumors. His major publications in the neurosurgical literature began to appear around 1976, after approximately 12 years of working diligently in the field. By that time, he had amassed a huge clinical experience at Sick Kids, which enabled him to become an authority on virtually every topic in pediatric neurosurgery (82). He was tireless in his documentation of clinical case materials, amassing thousands of slides and photographs of cases that chronicled the state-of-the-art treatment of children with neurosurgical disease at the time. Many of his slides and case materials have been preserved for posterity on the Division of Neurosurgery web site (www.surg.med.utoronto.ca/neuro/ slides.html). By the time he retired from neurosurgical practice, he had published more than 200 peer-reviewed articles on pediatric neurosurgery topics on which he had become an authority such as craniopharyngioma, tethered cord, spina bifida, Chiari malformation, moyamoya disease, and epilepsy surgery (Table 1) $(9,25,28,30,38,42,73,77,91)$. Dr. Hoffman's final major scientific contribution to pediatric neurosurgery was acknowledged in the August 2004 issue of Child's Nervous System (83), in which he pioneered the use of interventional neuroradiological and neuronavigation techniques to separate craniopagus twins in 1995.

Dr. Hoffman quickly demonstrated his inquisitive enthusiasm for the investigation and treatment of a child's nerv- 
ous system disorder; he left no stone unturned in his quest for clinical solutions. He put in very long days, often joining the residents side-by-side in their ward and emergency room duties. He initiated a laboratory project to study the value of dexamethasone treatment for focal brain edema. Early in his career, when he was not in the laboratory, operating room, radiology, or his Monday morning clinics, he would be off to Sunnybrook Hospital for his once-weekly commitment there. For all of his tireless and inspirational confidence and enthusiasm, Dr. Hoffman was not without his foibles and eccentricities. For example, he was perhaps the only neurosurgeon who wore a monacle and, on formal occasions, pince-nez (82).

Another one of Dr. Hoffman's most notable characteristics was his desire to stay current with or, at times, ahead of the latest neurosurgical technologies. He had a passion for understanding mechanical gadgets that ranged from wristwatches to automobiles (56). It is no small wonder that he insisted that the Hospital for Sick Children would be at the forefront of acquiring cutting-edge technologies such as mouth-driven microscopes, lasers, ultrasonic tumor aspirators, and image-guided therapy. Regarding the latter, Dr. Hoffman secured the ISGviewing wand (SNS, Inc., Toronto, Canada) in 1992, making Sick Kids the first pediatric neurosurgery service in the world to use neuronavigation in the resection of complex pediatric brain tumors (11). Dr. Hoffman's ingenuity also led to the design of new equipment for pediatric neurosurgery cases. He invented two types of shunt devices for hydrocephalus: the lumboperitoneal shunt, the so-called Hoffman T-tube shunt, and one of the world's first "uni-shunts," designed with his colleague and friend, Dr. Fred Epstein, to avoid problems of shunt disconnections and breakages.

During his career in pediatric neurosurgery, Dr. Hoffman received numerous honors, including the Lister Prize in the Department of Surgery at the University of Toronto and the Donald Matson Memorial lecture given by the American Association of Neurological Surgeons in 1996. He held several major offices in organized neurosurgery during his career. He was President of the American Society of Pediatric Neurosurgery from 1980 to 1982, President of the International Society of Pediatric Neurosurgery in 1983 and 1984, Chairman of the Pediatric Section of the American Association of Neurological Surgeons/Congress of Neurological Surgeons in 1983, and President of the Canadian Neurosurgical Society and Vice President for North America of the World Federation of Neurosurgical Societies from 1993 to 1996. In 1986, he was appointed Neurosurgeon-in-Chief at the Hospital for Sick Children (Fig. 5C) for a term that would span 10 years. In 1998, after his retirement, the Harold J. Hoffman/Shoppers Drug Mart Chair in Pediatric Neurosurgery was established at Sick Kids.

Dr. Hoffman died in 2004 from complications related to frontal lobe atrophy. In 2006, the Hoffman family established the Harold and JoAnn Hoffman lectureship in Pediatric Neurosurgery, which is delivered annually on the occasion of the annual meeting of the American Society of Pediatric Neurosurgery.

\section{Robin P. Humphreys}

Dr. Robin Humphreys received all of his formal education in Toronto, where he graduated from the University of Toronto Faculty of Medicine in 1962. He began his internship in Toronto at St. Michael's Hospital in orthopedics but was captivated by a rotation in neurosurgery (81). After much soul searching, he made the fateful decision to change career paths and entered the neurosurgery training program at the University of Toronto. He became a Fellow of the Royal College of Surgeons in Neurosurgery in 1970 and a staff surgeon at the Hospital for Sick Children on the recommendation of the Neurosurgeon-inChief, Dr. E. Bruce Hendrick. Dr. Hendrick's plan for Dr. Humphreys to complete a 1-year fellowship with Dr. Donald Matson in Boston and then Mr. Kenneth Till in London, England went awry when Dr. Matson succumbed to a serious illness and Mr. Till organized his own retirement just before Dr. Humphreys' departure for his fellowship. Instead, Dr. Hendrick announced to Dr. Humphreys, "You might as well learn on the job" (55, p 100).

In the years that followed Dr. Humphreys' addition to the neurosurgical staff, the case volume accelerated exponentially (81). He initiated the Craniofacial Program at the Hospital for Sick Children along with Dr. Ian Munro and became an expert in the care of children with spina bifida and vascular malformations. He established a structured teaching program to help residents and fellows learn the nuances of pediatric neurosurgery. He continues to personally meet with the fellows and residents in monthly teaching sessions as an Emeritus Professor.

Dr. Humphreys was president of the American Society of Pediatric Neurosurgery in 1992 and 1993 and the International Society for Pediatric Neurosurgery from 1993 to 1994. He has been on the editorial boards for Pediatric Neurosurgery and Neurosurgery. He was awarded the Donald Matson Lectureship by the American Association of Neurological Surgeons / Congress of Neurological Surgeons Section on Pediatric Neurosurgery in 2003 and the Hospital for Sick Children Foundation Claus Wirsig Humanitarian Award in 2003 (79). He was Neurosurgeon-in-Chief at the Hospital for Sick Children from 1996 to 2003 and the Chairholder of the Harold J. Hoffman/ Shoppers Drug Mart chair in pediatric neurosurgery at that time (Fig. 5D).

Dr. Humphreys retired after 33 years of devoted service to the Pediatric Neurosurgery Program at the Hospital for Sick Children, completing a glorious chapter in the history of pediatric neurosurgery at the Hospital for Sick Children that began with the "3 Hs" (81). Working with Dr. Hoffman, Dr. Humphreys helped to write the next chapter in the history of pediatric neurosurgery with the recruitment of Drs. James Drake and James Rutka (the "2 Jims") to the service (Fig. 6) (81).

It is almost impossible to describe the impact of the dynasty created at the Hospital for Sick Children by the union of the first three full-time pediatric neurosurgeons (82). 


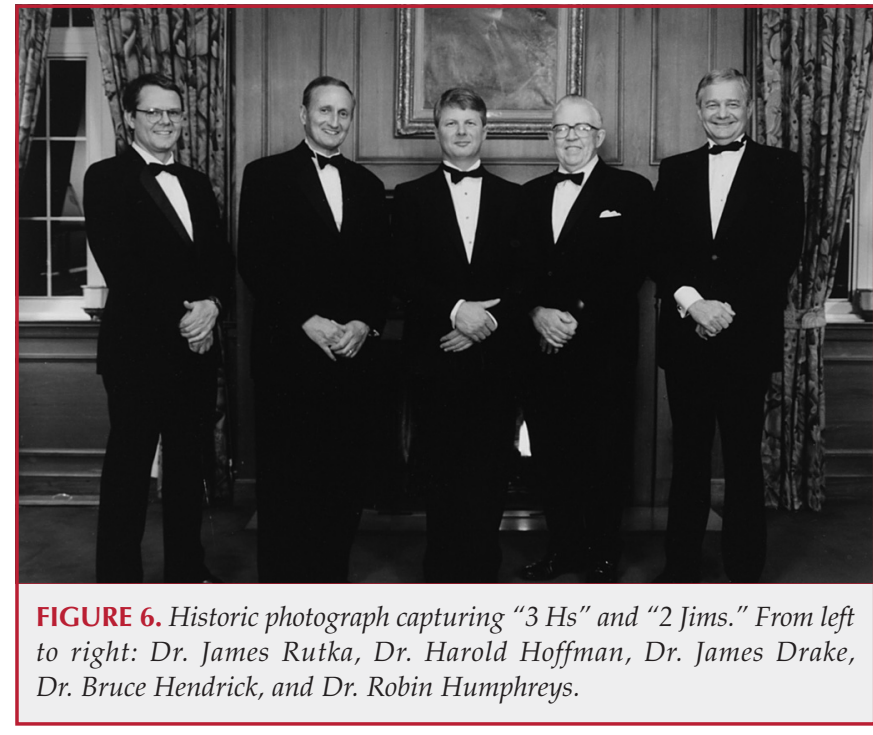

The moniker, the "3 Hs" (82), short for Drs. Hendrick, Hoffman, and Humphreys, was actually coined by Mr. Kenneth Till (RP Humphreys, personal communication, September 7, 2006). Collectively, they coauthored some of the most important works published on pediatric neurosurgery topics in the literature (Table 1). Their worldwide visibility in pediatric neurosurgery placed the Hospital for Sick Children on the map for being one of the busiest services in the world. Accordingly, during their administration, the Sick Kids service in neurosurgery attracted fellows and faculty from all corners of the globe, a practice that has continued to this day (Appendix 1).

\section{THE NEXT GENERATION: A FOCUS ON THE SURGEON-SCIENTIST}

\section{James M. Drake}

Dr. James Drake (Fig. 6) attended Princeton University from 1969 to 1974, receiving a degree in aerospace and mechanical engineering. He then received his medical education at the Royal College of Surgeons in Ireland, graduating in 1979. In 1982, Dr. Drake entered the Neurosurgery Training Program at the University of Toronto. He received his Master's degree in magnetic resonance imaging of hydrocephalus in 1987 at the University of Toronto. In the same year, he became a Fellow of the Royal College of Surgeons of Canada. After a Clinical Fellowship in Pediatric Neurosurgery at l'Hôpital Necker-Enfants Malades in Paris, Dr. Drake joined the neurosurgical staff at the Hospital for Sick Children in 1988. He promptly established the Hydrocephalus Research Laboratory and began working on the application of robotics to the resection of pediatric brain tumors (10). He is an author of more than 150 peer-reviewed publications, including the definitive textbook on cerebrospinal fluid shunts, The Shunt Book, which he coauthored with Professor Christian Sainte-Rose of Paris. He is currently a Full Professor in the Department of Surgery and succeeded Dr. Robin Humphreys as the Division's fifth Neurosurgeonin-Chief on Dr. Humphreys' retirement in 2003. He is the current Harold J. Hoffman/Shopper's Drug Mart Chair in Pediatric Neurosurgery. His clinical practice focuses on hydrocephalus, spasticity, neuroendoscopic procedures, the pediatric spine, and peripheral nerve surgery. His research is devoted to engineering a better cerebrospinal fluid shunt design system and mathematical models of hydrocephalus.

\section{James T. Rutka}

Dr. James Rutka (Fig. 6) was educated at Princeton University from 1975 to 1977 and Queen's University Medical School from 1977 to 1981 . He entered the Neurosurgery Training Program at the University of Toronto in 1982. He undertook basic science research studies in Experimental Neuro-oncology at the Brain Tumor Research Center at the University of California, San Francisco, from 1984 to 1987 where he also received his Ph.D. in Experimental Pathology before returning to Toronto to complete his neurosurgery residency. He became a Fellow of the Royal College of Surgeons in Canada in 1989.

After a Clinical-Research Fellowship in Japan as a Kenichiro Sugita Fellow, Dr. Rutka joined the Neurosurgical Staff at the Hospital for Sick Children in 1990. His clinical practice is devoted to the care of children with epilepsy and brain tumors. In 1997, he helped to establish the first brain tumor research center in Canada with the generous gift of business magnate, Arthur Labatt, and his wife, Sonia. He is currently codirector of the Labatt Brain Tumor Research Center (www.sickkids. ca/BTRC/), which houses eight principal investigators and more than 50 research associates, graduate students, and fellows. Dr. Rutka became Chairman of the Division of Neurosurgery at the University of Toronto in 1999, a position he will hold for 10 years.

\section{Peter B. Dirks}

Dr. Peter Dirks (Fig. 7A) is a 1989 graduate of Queen's University Medical School. He entered the Neurosurgery Training Program at the University of Toronto in 1990. During his neurosurgical training, he undertook research studies as a graduate student in experimental neuro-oncology in Dr. Rutka's laboratory. He received a Ph.D. in Cellular and Molecular Pathology in 1998. Dr. Dirks became a Fellow of the Royal College of Physicians and Surgeons of Canada in 1998.

After a clinical fellowship in pediatric neurosurgery at l'Hôpital Necker-Enfants Malades in Paris in 1998, he began his neurosurgical staff appointment at the Hospital for Sick Children in 1998. He is currently an associate professor in the Department of Surgery at the University of Toronto.

His clinical practice is devoted to children with vascular, head injuries, spinal dysraphism, and neoplastic diseases of the nervous system. His research laboratory is within the Arthur and Sonia Labatt Brain Tumor Research Center at the Hospital for Sick Children where he is currently conducting 


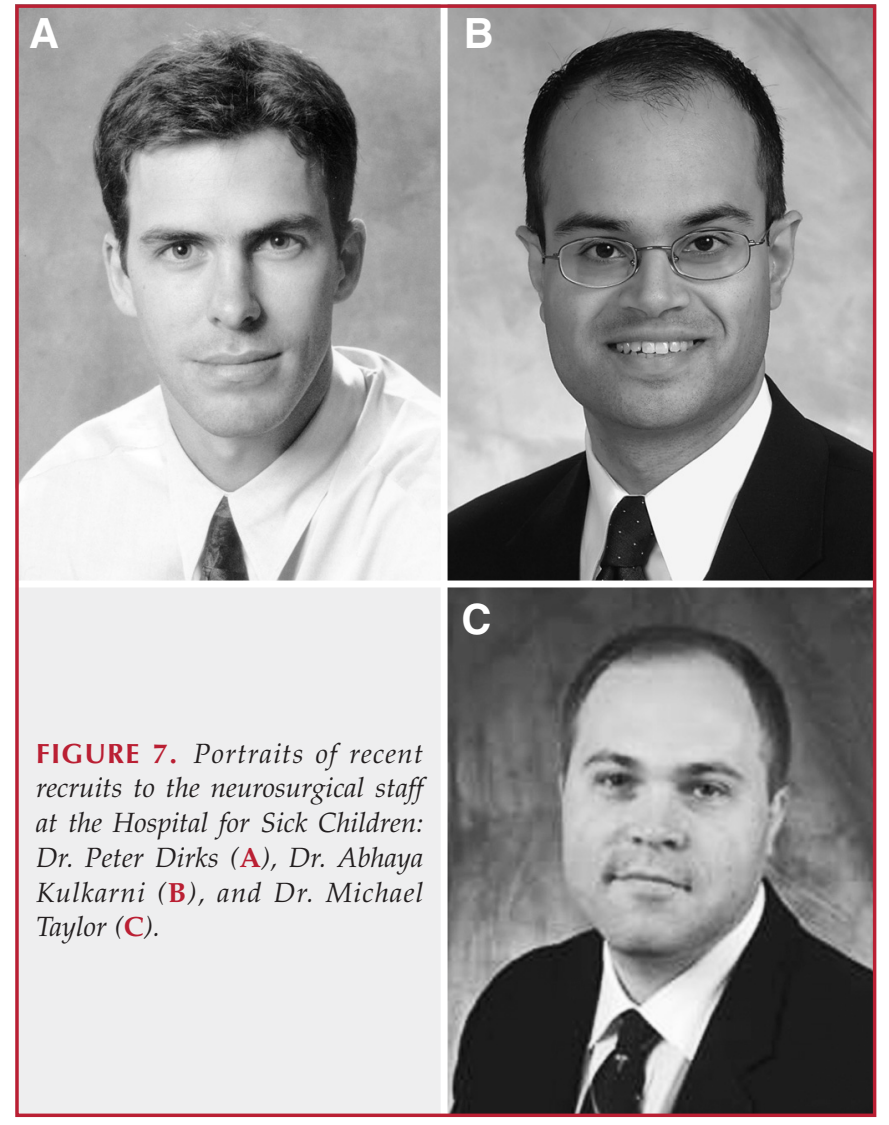

research in stem cells and cell cycle pathways as a principal investigator $(7,8,85,86)$.

\section{Abhaya V. Kulkarni}

Dr. Abhaya Kulkarni (Fig. 7B) completed his residency in the Neurosurgery Training Program at the University of Toronto in 2002. During his training, Dr. Kulkarni published several peer-reviewed articles and was awarded numerous citations, including the Congress of Neurological Surgeons Resident Award and the McKenzie Prize in Clinical Neurosciences. He received specialized training as a clinical fellow at l'Hôpital Necker-Enfants Malades in pediatric neurosurgery. In Paris, Dr. Kulkarni completed and published a widely quoted study on the conservative management of children with spinal lipomas (64).

Dr. Kulkarni joined the neurosurgical staff at the Hospital for Sick Children in 2003. He successfully completed his graduate studies and has received a Ph.D. in Clinical Epidemiology from McMaster University. Dr. Kulkarni brings his expertise on evidence-based medicine and clinical epidemiology to the Hospital for Sick Children, where he continues his role in organizing and conducting clinical trials in neurosurgery. He also holds an appointment in the Hospital for Sick Children Research Institute in Population Health Sciences.

\section{Michael D. Taylor}

Dr. Michael Taylor (Fig. 7C) is a 2003 graduate of the University of Toronto Neurosurgery Training Program. He received his Ph.D. in Dr. Rutka's laboratory in the Labatt Brain Tumor Research Centre in Laboratory Medicine and Pathobiology in 2002. He completed a clinical fellowship in pediatric neurosurgery at Le Bonheur Hospital for Children in Memphis, Tennessee, under the auspices of Drs. Robert Sanford and Frederick Boop. That same year, he spent time as a postdoctoral fellow in the Department of Developmental Neurobiology at St. Jude's Children's Research Hospital.

Dr. Taylor joined the staff at the Hospital for Sick Children in 2004 as a faculty neurosurgeon in the Department of Surgery and as a principal investigator in the Labatt Brain Tumor Research Center where he is studying the molecular genetic underpinnings of medulloblastoma and ependymoma.

The Division of Neurosurgery at the Hospital for Sick Children today receives approximately $\$ 2$ million annually of peer-reviewed funding from various sources, including the National Cancer Institute of Canada, the Canadian Institutes of Health Research, the Ontario Cancer Research Network, the Pediatric Brain Tumor Foundation, and the Natural Sciences and Engineering Research Council of Canada (JT Rutka, personal communication, March 10, 2007).

\section{THE TRAINEES: FROM FAR AND WIDE}

In April 1988, more than 100 past residents and fellows gathered in Toronto at the King Edward Hotel for a Hospital for Sick Children neurosurgical reunion dinner (28). The men and women who have rotated through the Hospital for Sick Children as pediatric neurosurgical residents or fellows have brought their skills and knowledge to the Hospital. They have shared this knowledge with the medical students, other residents and fellows, and the staff. Their talents have been noted in the emergency room, operating room, intensive care unit, outpatient clinics, and inpatient wards. They have all added to the fabric of the institution by their interactions with the neurosurgical staff. A review of the locations of the trainees from Sick Kids reveals their positions in five provinces in Canada, 28 states in the United States, and 16 other countries around the world, including Argentina, Australia, Brazil, Great Britain, Ireland, Germany, Israel, Japan, Thailand, Taiwan, South Korea, the Philippines, Saudi Arabia, France, Italy, and South Africa.

In the Neurosurgery Office at Sick Kids, the portraits of former fellows and trainees are proudly displayed. The purpose of the fellowship program is to train, foster, and nurture tomorrow's leadership of pediatric neurosurgery. Some of the leaders of modern-day pediatric neurosurgery who have graced Sick Kids as fellows and residents are listed in Appendices 1 and 2.

\section{CONCLUSION}

Nine years after Dr. Kenneth G. McKenzie established neurosurgery in Canada at the Toronto General Hospital, Dr. 
William S. Keith was appointed to the Hospital for Sick Children in 1933. He was the first neurosurgeon in the Hospital's 58-year history. Although his appointment was only part-time, he nevertheless began a tradition of pediatric neurosurgery that has flourished for seven decades at the Hospital for Sick Children in Toronto.

The future goals of the Division of Neurosurgery at the Hospital for Sick Children in Toronto are to maintain its position as an outstanding unit for the care of children with neurosurgical disorders and to continue research in the fields of hydrocephalus, congenital malformations, brain tumors, clinical epidemiology, and clinical trials design. It is expected that the neurosurgical service will continue to train the best and brightest for future careers in pediatric neurosurgery. It is hoped that the mandate for dedication to the academic mission will be maintained through the establishment of future endowed chairs to commemorate and honor the founding fathers who gave rise to the neurosurgery service. The final and perhaps most important mandate of the Division is to continue providing leading-edge clinical care to the youngest of patients and education for the next generation of pediatric neurosurgeons.

\section{REFERENCES}

1. Alexander E Jr: Kenneth George McKenzie, Canada's first neurosurgeon. J Neurosurg 41:1-9, 1974.

2. Asai A, Hoffman HJ, Hendrick EB, Humphreys RP, Becker LE: Primary intracranial neoplasms in the first year of life. Childs Nerv Syst 5:230-233, 1989.

3. Bernstein M, Hoffman HJ, Halliday WC, Hendrick EB, Humphreys RP: Thalamic tumors in children. Long-term follow-up and treatment guidelines. J Neurosurg 61:649-656, 1984.

4. Braithwaite M: Sick Kids: The Story of the Hospital for Sick Children in Toronto. Toronto, McClelland and Steward Limited, 1974, pp 9-18.

5. Choi JU, Hoffman HJ, Hendrick EB, Humphreys RP, Keith WS: Traumatic infarction of the spinal cord in children. J Neurosurg 65:608-610, 1986.

6. Cremin BJ: Derek Harwood-Nash obituaries. Pediatr Radiol 27:778, 1997.

7. Dirks PB: Glioma migration: Clues from the biology of neural progenitor cells and embryonic CNS cell migration. J Neurooncol 53:203-212, 2001.

8. Dirks PB: Brain tumor stem cells. Biol Blood Marrow Transplant 11:12-13, 2005.

9. Drake J, Hoffman HJ, Kobayashi J, Hwang P, Becker LE: Surgical management of children with temporal lobe epilepsy and mass lesions. Neurosurgery 21:792-797, 1987.

10. Drake JM, Joy M, Goldenberg A, Kreindler D: Computer- and robot-assisted resection of thalamic astrocytomas in children. Neurosurgery 29:27-33, 1991.

11. Drake JM, Prudencio J, Holowka S, Rutka JT, Hoffman HJ, Humphreys RP: Frameless stereotaxy in children. Pediatr Neurosurg 20:152-159, 1994.

12. Findlay JM: Neurosurgery at the Toronto General Hospital, 1924-1990: Part 1. Can J Neurol Sci 21:146-148, 1994.

13. Findlay JM: Neurosurgery at the Toronto General Hospital, 1924-1990: Part 2. Can J Neurol Sci 21:278-284, 1994.

14. Fleming R: In memoriam: William Stathearn Keith (1902-1987). Can J Neurol Sci $15: 165-166,1988$

15. Garrido E, Becker LF, Hoffman HJ, Hendrick EB, Humphreys R: Gangliogliomas in children. A clinicopathological study. Childs Brain 4:339-346, 1978.

16. Garrido E, Humphreys RP, Hendrick EB, Hoffman HJ: Lumbar disc disease in children. Neurosurgery 2:22-26, 1978.

17. Haddad MJ: Sick Kids Annual Report 2005-2006. www.sickkids.ca/annual report2005_2006/SKAR0506.pdf. Accessed March 5, 2007.

18. Harwood-Nash DC, Hendrick EB, Hudson AR: The significance of skull fracture in children. A study of 1,187 patients. Radiology 101:151-156, 1971.
19. Hendrick EB: The use of hypothermia in severe head injuries in childhood. Arch Surg 79:362-364, 1959.

20. Hendrick EB: Whatever mother says! Pediatr Neurosci 12:193, 1985.

21. Hendrick EB, Harris L: Post-traumatic epilepsy in children. J Trauma 8:547-556, 1968.

22. Hendrick EB, Harwood-Nash DC, Hudson AR: Head injuries in children: A survey of 4465 consecutive cases at the Hospital for Sick Children, Toronto, Canada. Clin Neurosurg 11:46-65, 1964.

23. Hendrick EB, Hoffman HJ, Hudson AR: Hemispherectomy in children. Clin Neurosurg 16:315-327, 1969

24. Hendrick EB, Hoffman HJ, Humphreys RP: The tethered spinal cord. Clin Neurosurg 30:457-463, 1983.

25. Hodaie M, Musharbach A, Otsubo H, Snead OC 3rd, Chitoku S, Ochi A, Holowka S, Hoffman HJ, Rutka JT: Image-guided, frameless stereotactic sectioning of the corpus callosum in children with intractable epilepsy. Pediatr Neurosurg 34:286-294, 2001

26. Hoffman HJ: Biography: Dr. William S. Keith. Childs Nerv Syst 3:195-196, 1987.

27. Hoffman HJ: E. Bruce Hendrick. Surg Neurol 33:171-172, 1990.

28. Hoffman HJ: Moyamoya disease and syndrome. Clin Neurol Neurosurg 99 [Suppl 2]:S39-S44, 1997.

29. Hoffman HJ, Chuang S, Hendrick EB, Humphreys RP: Aneurysms of the vein of Galen. Experience at the Hospital for Sick Children, Toronto. J Neurosurg 57:316-322, 1982.

30. Hoffman HJ, De Silva M, Humphreys RP, Drake JM, Smith ML, Blaser SI: Aggressive surgical management of craniopharyngioma in children. J Neurosurg 76:47-52, 1992.

31. Hoffman HJ, Harwood-Nash DC, Gilday DL: Percutaneous third ventriculostomy in the management of non-communicating hydrocephalus. Neurosurgery 7:313-321, 1980.

32. Hoffman HJ, Hendrick EB: Early neurosurgical repair in craniofacial dysmorphism. J Neurosurg 51:796-803, 1979.

33. Hoffman HJ, Hendrick EB, Dennis M, Armstrong D: Hemispherectomy for Sturge-Weber syndrome. Childs Brain 5:233-248, 1979.

34. Hoffman HJ, Hendrick EB, Hiscox JL: Cerebral abscesses in early infancy. J Neurosurg 33:172-177, 1970.

35. Hoffman HJ, Hendrick EB, Humphreys RP: Manifestations and management of the Arnold-Chiari malformation in patients with myelomeningocele. Childs Brain 1:255-259, 1975.

36. Hoffman HJ, Hendrick EB, Humphreys RP: Metastasis via ventriculoperitoneal shunt in patients with medulloblastoma. J Neurosurg 44:562-566, 1976.

37. Hoffman HJ, Hendrick EB, Humphreys RP: New lumboperitoneal shunt for communicating hydrocephalus: Technical note. J Neurosurg 44:258-261, 1976.

38. Hoffman HJ, Hendrick EB, Humphreys RP: The tethered spinal cord: Its protean manifestations, diagnosis, and surgical correction. Childs Brain 2:145-155, 1976.

39. Hoffman HJ, Hendrick EB, Humphreys RP: Experience with ventriculopleural shunts. Childs Brain 10:404-413, 1983.

40. Hoffman HJ, Hendrick EB, Humphreys RP: Management of medulloblastoma. Clin Neurosurg 30:189-202, 1983.

41. Hoffman HJ, Hendrick EB, Humphreys RP, Armstrong EA: Investigation and management of suprasellar arachnoid cysts. J Neurosurg 57:597-602, 1982.

42. Hoffman HJ, Hendrick EB, Humphreys RP, Buncic JR, Armstrong DL, Jenkin RD: Management of craniopharyngioma in children. J Neurosurg 47:218-227, 1977.

43. Hoffman HJ, Humphreys RP, Drake JM, Rutka JT, Becker LE, Jenkin D, Greenberg M: Optic pathway/hypothalamic gliomas: A dilemma in management. Pediatr Neurosurg 19:186-195, 1993.

44. Hoffman HJ, Mohr G: Lateral canthal advancement of the supraorbital margin. A new corrective technique in the treatment of coronal synostosis. J Neurosurg 45:371-381, 1976.

45. Hoffman HJ, Neill J, Crone KR, Hendrick EB, Humphreys RP: Hydrosyringomyelia and its management in childhood. Neurosurgery 21:347-351, 1987.

46. Hoffman HJ, Otsubo H, Hendrick EB, Humphreys RP, Drake JM, Becker LE, Greenberg M, Jenkin D: Intracranial germ-cell tumors in children. J Neurosurg 74:545-551, 1991.

47. Hoffman HJ, Soloniuk DS, Humphreys RP, Drake JM, Becker LE, De Lima BO, Piatt JH Jr: Management and outcome of low-grade astrocytomas of the midline in children: A retrospective review. Neurosurgery 33:964-971, 1993. 
APPENDIX 1. Chief fellows and visiting fellows trained at the Hospital for Sick Children in pediatric neurosurgery

\begin{tabular}{|c|c|}
\hline Term of service & Fellows \\
\hline July 1, 1969-June 30, 1970 & Dr. J. Gary Ashby \\
\hline July 1-December 15, 1970 & Dr. Robin P. Humphreys \\
\hline July 1, 1970-June 30, 1971 & Dr. Miguel S. Garrote \\
\hline January 1-December 31, 1972 & Dr. Andrew J. Joaquin \\
\hline January 1-June 30, 1973 & Dr. John M. Crouch \\
\hline July 1-December 31, 1976 & Dr. Renn O. Holness \\
\hline January 1-March 30, 1977 & Dr. Edward Garrido \\
\hline January 1-June 30, 1977 & Dr. Michael Feely \\
\hline July 1-December 31, 1978 & Dr. Dachling Pang \\
\hline July 1-December 31, 1979 & Dr. Warren S. Ishida \\
\hline April 1-December 31, 1980 & Dr. Toru Shirouzu \\
\hline January 1, 1980-February 28, 1981 & Dr. Tai-Tong Wong \\
\hline January 1-March 31, 1981 & Dr. Toru Shirouzu \\
\hline January 1-December 31, 1981 & Dr. Diogenes A. Harris \\
\hline April 1, 1981-March 31, 1982 & Dr. Tae Sung Park \\
\hline August 1, 1981-August 31, 1982 & Dr. Shigetake Anegawa \\
\hline January 1-December 31, 1982 & Dr. Masafumi Yoshida \\
\hline January 15-June 30, 1983 & Dr. Akira Ishibashi \\
\hline August 9, 1982-December 31, 1983 & Dr. Chopeow Taecholarn \\
\hline January 1-June 30, 1984 & Dr. David S. Knierim \\
\hline July 1-December 31, 1984 & Dr. Beverly C. Walters \\
\hline September 25-December 31, 1984 & Dr. Shigeru Nemoto \\
\hline October 1984-September 30, 1985 & Dr. Joong Uhn Choi \\
\hline January 1-June 30, 1985 & Dr. Ann R. Stroink \\
\hline July 1, 1985-June 30, 1986 & Dr. Robert W. Griebel \\
\hline January 1-June 30, 1986 & Dr. Mitchel S. Berger \\
\hline January 1-June 30, 1986 & Dr. John Johnson \\
\hline July 1-December 31, 1986 & Dr. Corey Raffel \\
\hline January 1-July 30, 1987 & Dr. Robert J. Backer \\
\hline January 1-March 31, 1987 & Dr. Denis Ladoucer \\
\hline January 1-July 30, 1987 & Dr. Padraic O’Neill \\
\hline July 1, 1987-June 30, 1988 & Dr. Liliana Goumnerova \\
\hline September 1, 1987-August 31, 1988 & Dr. Akio Asai \\
\hline July 1-December 31, 1988 & Dr. Tai Ngar Lui \\
\hline October 1-December 31, 1988 & Dr. Carolyn Wright \\
\hline July 1, 1988-June 30, 1989 & Dr. Semion Rochkind \\
\hline July 1, 1988-June 30, 1989 & Dr. Richard E. George \\
\hline July 1, 1988-June 30, 1989 & Dr. Benicio Oton de Lima \\
\hline April 1, 1988-December 31, 1989 & Dr. Hiroshi Otsubo \\
\hline January 23-July 31, 1989 & Dr. Judith A. Murovic \\
\hline July 1-December 31, 1989 & Dr. Dong Won Kim \\
\hline September 11-October 11, 1989 & Dr. Anita North \\
\hline July 1,1988 -June 30,1990 & Dr. Marcia da Silva \\
\hline July 1, 1989-June 30, 1990 & Dr. Antonio R. Mock \\
\hline July 1, 1989-June 30, 1990 & Dr. Samuel Keith St. Clair \\
\hline January 1-June 30, 1990 & Dr. Hiroshi Otsubo \\
\hline January 1-June 30, 1990 & Dr. Donald S. Soloniuk \\
\hline July 1, 1989-June 30, 1991 & Dr. Shalom D. Michowiz \\
\hline July 1, 1990-June 30, 1991 & Dr. Lewis W. Harris \\
\hline July 1, 1990-June 30, 1991 & Dr. Rosemaria Gennuso \\
\hline July 1-September 30, 1991 & Dr. Ian F. Pollock \\
\hline July 1-October 31, 1991 & Dr. Premkumar Pillay \\
\hline
\end{tabular}

APPENDIX 1. (continued)

Term of service

July 1, 1991-June 30, 1992

May 1-August 15, 1992

July 1, 1991-June 30, 1993

July 1, 1992-June 30, 1993

September 1, 1992-June 30, 1993

September 1, 1992-October 31, 1993

July 1, 1993-June 30, 1994

July 1, 1993-June 30, 1994

July 1, 1993-October 31, 1994

July 1, 1994-June 30, 1995

November 23, 1994-August 15, 1995

July 1, 1995-February 15, 1996

July 1, 1995-June 30, 1997

October 15, 1995-June 30, 1997

July 1, 1996-June 30, 1997

February 1-May 31, 1997

May 1, 1997-June 30, 1998

July 1, 1997-June 30, 1998

September 1, 1997-February 28, 1998

July 1, 1998-June 30, 1999

July 1, 1998-December 18, 1999

February 1, 1999-January 31, 2000

July 1, 1999-June 30, 2000

July 1, 1999-April 3, 2000

February 1, 2000-January 31, 2001

July 1, 2000-June 30, 2001

July 1, 2000-June 30, 2001

January 1- June 30, 2001

February 1-December 31, 2001

July I-December 31, 2001

July 1, 2001-June 30, 2002

July I, 2001-June 30, 2002

January 1-June 30, 2002

November 1, 2001-February 28, 2003

July 1, 2002-June 30, 2003

July 1, 2002-June 30, 2003

July 1, 2002-June 30, 2003

July 1, 2002-June 30, 2003

July 1, 2003-June 30, 2004

March 1, 2003-December 31, 2004

July 1, 2003-June 30, 2004

September 1, 2003-September 30, 2004

June 1-November 30, 2004

January 1-June 30, 2005

July 1, 2004-June 30, 2005

July 1, 2004-June 30, 2006

July $1-$ October 15, 2005

July 1, 2005-June 30, 2006

July 1, 2005-June 30, 2006

August 30, 2005-January 3, 2006

January 1-December 30, 2006

July 1, 2006-June 30, 2007

July 1, 2006-June 30, 2007
Fellows

Dr. John R.W. Kestle

Dr. Paul D. Chumas

Dr. Abraham Cohen

Dr. John A. Duncan III

Dr. Marcia da Silva

Dr. Mehdi Abdolahzadeh

Dr. Andre Turmel

Dr. Daniela Stritt

Dr. Hanoch Elran

Dr. Mark Souweidane

Dr. Young Shin Ra

Dr. Maria Varela-Stavrinou

Dr. Essam Al-Shail

Dr. Kahil Salame

Dr. John Myseros

Dr. Franck-Emmauel Roux

Dr. Awni Musharbash

Dr. Nalin Gupta

Dr. Anantha Kishan

Dr. Mark lantosca

Dr. Lynn Myles

Dr. Teresa K. Withers

Dr. Jeffrey P. Blount

Dr. Dwight Webster

Dr. Patrick Lo

Dr. Walter Hader

Dr. Hussam Kutub

Dr. Wilson Ho

Dr. Torben Hansen

Dr. Carl Bruce

Dr. Stephen Santorenos

Dr. Patrick McDonald

Dr. Mamoud Rashidi

Dr. Hisashi Hatano

Dr. William Whitehead

Dr. Michael Carter

Dr. Aurelia Peraud

Dr. Raafat Yahya

Dr. John Jane, Jr.

Dr. Takashi Araki

Dr. Jayaratnam Jayamohan

Dr. Francesco Sala

Dr. Amit Ray

Dr. Takashi Araki

Dr. Sami Khoshyomn

Dr. Mony Benifla

Dr. Neermala Dasi

Dr. Jay Riva-Cambrin

Dr. Richard Edwards

Dr. Bart Depreitere

Dr. Zulma Tovar-Spinoza

Dr. Andrew Jea

Dr. Sandrine de Ribaupierre 
APPENDIX 2. Selected residents rotated through the Hospital for Sick Chldren in pediatric neurosurgery

\begin{tabular}{|c|c|}
\hline Residency term & Residents \\
\hline July 1-December 31, 1970 & Dr. William Shucart \\
\hline July 1-December 31, 1971 & Dr. Paul Chapman \\
\hline July 1, 1972-June 30, 1973 & Dr. Marion L. Walker \\
\hline January 1-June 30, 1975 & Dr. Anthony D. Hockley \\
\hline July 1-December 31, 1975 & Dr. W. Jerry Oakes \\
\hline July 1-December 31, 1976 & Dr. Haring Nauta \\
\hline July 1-December 31, 1976 & Dr. Guy Sava \\
\hline January 1-June 30, 1977 & Dr. Kotoo Meguro \\
\hline July 1-December 31, 1978 & Dr. Warwick J. Peacock \\
\hline January 1-June 30, 1979 & Dr. Michael Besser \\
\hline July 1-December 31, 1980 & Dr. Bruce B. Storrs \\
\hline January 1-June 30, 1981 & Dr. Harold P. Smith \\
\hline July 1-December 31, 1982 & Dr. Patricia A. Aronin \\
\hline July 1, 1982-December 31, 1983 & Dr. Jonathon Punt \\
\hline October 1-December 31, 1982 & Dr. Kamel Muakkassa \\
\hline January 1-June 30, 1984 & Dr. Nasri J. S. Khoury \\
\hline January 1-June 30, 1984 & Dr. Bruce Tranmer \\
\hline January 1-June 30, 1985 & Dr. Beverly C. Walters \\
\hline July 1-December 31, 1985 & Dr. Kerry R. Crone \\
\hline July 1-December 31, 1985 & Dr. Kim H. Manwaring \\
\hline January 1-June 30, 1986 & Dr. Fred A. Lenz \\
\hline July 1, 1986-June 30, 1987 & Dr. Joseph H. Piatt \\
\hline August 1-September 30, 1987 & Dr. Frederick A. Boop \\
\hline January 1-June 30, 1989 & Dr. Douglas Kondziolka \\
\hline July 1-September 30, 1989 & Dr. Allan Levi \\
\hline July 1-December 31, 1994 & Dr. Hal Meltzer \\
\hline April 1-May 31, 2000 & Dr. David Sandberg \\
\hline
\end{tabular}

48. Hoffman HJ, Taecholarn C, Hendrick EB, Humphreys RP: Management of lipomyelomeningoceles. Experience at the Hospital for Sick Children, Toronto. J Neurosurg 62:1-8, 1985.

49. Hoffman HJ, Yoshida M, Becker LE, Hendrick EB, Humphreys RP: Pineal region tumors in children. Experience at the Hospital for Sick Children. 1983. Pediatr Neurosurg 21:91-103, 1994.

50. Holness RO, Hoffman HJ, Hendrick EB: Subtemporal decompression for 'the slit ventricle syndrome' after shunting in hydrocephalic children. Childs Brain 5:137-144, 1979.

51. Huckman MS: Derek F. C. Harwood-Nash, MB, ChB, DSc, FRCPC, FACR, FC RAD(SA). AJNR Am J Neuroradiol 18:1803-1812, 1997.

52. Humphreys RP: Complications of hemorrhagic stroke in children. Pediatr Neurosurg 17:163-168, 1991-1992.

53. Humphreys RP: Complications of pediatric head injury. Pediatr Neurosurg 17:274-278, 1991-1992.

54. Humphreys RP: A sixty year history of the division of neurosurgery at the Hospital for Sick Children, May 20, 1993. www.surg.med.utoronto.ca/neuro/ sickkids.html. Accessed September 8, 2006.

55. Humphreys RP: In memoriam: Edward Bruce Hendrick: January 20, 1924-August 17, 2001. Can J Neurol Sci 29:100-101, 2002.

56. Humphreys RP: In memory: Looking back at Harold Hoffman. University of Toronto. The Surgical Spotlight on Alumni, Faculty, Residents, and Friends:
12-13, Winter 2004-2005. www.surg.med.utoronto.ca/newsletter/newsletter Winter04-05.pdf. Accessed September 8, 2006.

57. Humphreys RP, Hendrick EB, Hoffman HJ: Arteriovenous malformations of the brainstem in childhood. Childs Brain 11:1-11, 1984.

58. Humphreys RP, Hendrick EB, Hoffman HJ: The head-injured child who 'talks and dies.' A report of 4 cases. Childs Nerv Syst 6:139-142, 1990.

59. Humphreys RP, Hoffman HJ, Drake JM, Rutka JT: Choices in the 1990s for the management of pediatric cerebral arteriovenous malformations. Pediatr Neurosurg 25:277-285, 1996.

60. Humphreys RP, Hoffman HJ, Hendrick EB: A long-term postoperative followup in craniopharyngioma. Childs Brain 5:530-539, 1979.

61. Keith WS: Traumatic infarction of the spinal cord. Can J Neurol Sci 1:124-126, 1974.

62. Keith WS: "Whiplash" injury of the 2nd cervical ganglion and nerve. Can J Neurol Sci 13:133-137, 1986.

63. Kondziolka D, Humphreys RP, Hoffman HJ, Hendrick EB, Drake JM: Arteriovenous malformations of the brain in children: A forty year experience. Can J Neurol Sci 19:40-45, 1992.

64. Kulkarni AV, Pierre-Kahn A, Zerah M: Conservative management of asymptomatic spinal lipomas of the conus. Neurosurgery 54:868-873, 2004.

65. Macdonald RL, Humphreys RP, Rutka JT, Kestle JR: Colloid cysts in children. Pediatr Neurosurg 20:169-177, 1994.

66. Macfarlane R, Rutka JT, Armstrong D, Phillips J, Posnick J, Forte V, Humphreys RP, Drake J, Hoffman HJ: Encephaloceles of the anterior cranial fossa. Pediatr Neurosurg 23:148-158, 1995.

67. May PL, Blaser SI, Hoffman HJ, Humphreys RP, Harwood-Nash DC: Benign intrinsic tectal 'tumours' in children. J Neurosurg 74:867-871, 1991.

68. Mohr G, Hoffman HJ, Munro IR, Hendrick EB, Humphreys RP: Surgical management of unilateral and bilateral coronal craniosynostosis: 21 years of experience. Neurosurgery 2:83-92, 1978.

69. Morley TM: A biographical sketch of Kenneth G. McKenzie (1892-1964). J Neurosurg 93:518-525, 2000.

70. Muakkassa KF, Hoffman HJ, Hinton DR, Hendrick EB, Humphreys RP, Ash J: Lambdoid synostosis. Part 2: Review of cases managed at the Hospital for Sick Children, 1972-1982. J Neurosurg 61:340-347, 1984.

71. Nazar GB, Hoffman HJ, Becker LE, Jenkin D, Humphreys RP, Hendrick EB: Infratentorial ependymomas in childhood: Prognostic factors and treatment. J Neurosurg 72:408-417, 1990.

72. Otsubo H, Hoffman HJ, Humphreys RP, Hendrick EB, Drake JM, Hwang PA, Becker LE, Chuang SH: Evaluation, surgical approach and outcome of seizure patients with gangliogliomas. Pediatr Neurosurg 16:208-212, 1990-1991.

73. Otsubo H, Hwang PA, Hunjan A, Armstrong D, Holowka S, Drake JM, Hoffman HJ: Use of frameless stereotaxy with location of electroencephalographic electrodes as three-dimensional computed tomographic images in epilepsy surgery. J Clin Neurophysiol 12:363-371, 1995.

74. Pannell BW, Hendrick EB, Hoffman HJ, Humphreys RP: Dermoid cysts of the anterior fontanelle. Neurosurgery 10:317-323, 1982.

75. Park TS, Hoffman HJ, Hendrick EB, Humphreys RP: Experience with surgical decompression of the Arnold-Chiari malformation in young infants with myelomeningocele. Neurosurgery 13:147-152, 1983.

76. Park TS, Hoffman HJ, Hendrick EB, Humphreys RP, Becker LE: Medulloblastoma: Clinical presentation and management. Experience at the Hospital for Sick Children, Toronto, 1950-1980. J Neurosurg 58:543-552, 1983.

77. Piatt JH Jr, Hwang PA, Armstrong DC, Becker LE, Hoffman HJ: Chronic focal encephalitis (Rasmussen syndrome): Six cases. Epilepsia 29:268-279, 1988.

78. Pollack IF, Hoffman HJ, Humphreys RP, Becker L: The long-term outcome after surgical treatment of dorsally exophytic brain-stem gliomas. J Neurosurg 78:859-863, 1993.

79. Raimondi AJ: Robin Paul Humphreys. Childs Nerv Syst 11:315-316, 1995.

80. Reigel DH: The founding editor-in-chief of Pediatric Neurosurgery. Pediatr Neurosurg 38:281-282, 2003.

81. Rutka JT: Robin Humphreys leaves HSC after 33 years of service to neurosurgery. University of Toronto. Surgery Newsletter for Alumni, Faculty, Residents, and Friends: 9, Fall 2003. www.bmc.med.utoronto.ca/newsletter/ newsletterFall03.pdf. Accessed September 8, 2006.

82. Rutka JT: In memory: Celebrating the life of Dr. Harold J. Hoffman, 1932-2004. University of Toronto. The Surgical Spotlight on Alumni, Faculty, 
Residents, and Friends: 11-12, Winter 2004-2005. www.surg.med.utoronto. ca/newsletter/newsletterWinter04-05.pdf. Accessed September 8, 2006.

83. Rutka JT, Souweidane M, ter Brugge K, Armstrong D, Zuker R, Clarke H, Creighton R, McLeod E, Khoury A, Hoffman HJ: Separation of craniopagus twins in the era of modern neuroimaging, interventional neuroradiology, and frameless stereotaxy. Childs Nerv Syst 20:587-592, 2004.

84. Schutz H, Fleming JF, Humphreys RP, Deck JH, Keith WS: Normal pressure hydrocephalus-high pressure normocephalus. Can J Neurol Sci 7:211-219, 1980.

85. Singh SK, Clarke ID, Hide T, Dirks PB: Cancer stem cells in nervous system tumors. Oncogene 23:7267-7273, 2004.

86. Singh SK, Hawkins C, Clarke ID, Squire JA, Bayani J, Hide T, Henkelman RM, Cusimano MD, Dirks PB: Identification of human brain tumour initiating cells. Nature 432:396-401, 2004.

87. Smith HP, Hendrick EB: Subdural empyema and epidural abscess in children. J Neurosurg 58:392-397, 1983.

88. Storrs BB, Humphreys RP, Hendrick EB, Hoffman HJ: Intracranial aneurysms in the pediatric age-group. Childs Brain 9:358-361, 1982.

89. Stroink AR, Hoffman HJ, Hendrick EB, Humphreys RP: Diagnosis and management of pediatric brain-stem gliomas. J Neurosurg 65:745-750, 1986.

90. Stroink AR, Hoffman HJ, Hendrick EB, Humphreys RP, Davidson G: Transependymal benign dorsally exophytic brain stem gliomas in childhood: Diagnosis and treatment recommendations. Neurosurgery 20:439-444, 1987.

91. Sugimoto T, Otsubo H, Hwang PA, Hoffman HJ, Jay V, Snead OC 3rd: Outcome of epilepsy surgery in the first three years of life. Epilepsia 40:560-565, 1999.

92. Vandertop WP, Asai A, Hoffman HJ, Drake JM, Humphreys RP, Rutka JT, Becker LE: Surgical decompression for symptomatic Chiari II malformation in neonates with myelomeningocele. J Neurosurg 77:541-544, 1992.

93. Walters BC, Hoffman HJ, Hendrick EB, Humphreys RP: Cerebrospinal fluid shunt infection. Influences on initial management and subsequent outcome. J Neurosurg 60:1014-1021, 1984.

\section{COMMENTS}

$T^{1}$ he esteemed reputation of Sick Kids is shadowed only by the personnel that have passed through her doors, most notably those who have spent their careers enriching our understanding of the field of pediatric neurosurgery. This treatise documenting the historical and contemporary era of that venerated hospital is long overdue and greatly appreciated. I have dedicated my career to caring for children with ailments of the central nervous system, and seldom does a day go by when I do not incorporate some "trick of the trade" inherited from Drs. Hoffman, Humphreys, Drake, or Rutka. Although the technical merit is the most immediate benefit acquired during my year at Sick Kids, I must recount two anecdotes that furthers the characterization of two individuals who manned the helm at various times.

The first of these accounts took place 1 month after my arrival in Toronto. I was invited to dine with Dr. Bruce Hendrick, a person I knew by name only, but nevertheless respected. His purpose was simple, to introduce himself, recount the history of Sick Kids, and engender a philosophical perspective on the profession that I chose to pursue. Before departing that afternoon, he generously presented a token of remembrance. He joyfully handed me a sculptured stone facsimile of the Country's national bird, a loon, which continues to rest on a bookcase in my office. Generous, thoughtful, and nostalgic were my first and lasting impressions of Dr. Hendrick.

The second narrative describes an event that left me with an eternal impression of the personal nature of Harold J. Hoffman. After 10 or so months that elapsed in my year-long adventure at Sick Kids, I was kindly invited to the home of Robin Humphreys for a backyard barbecue. I had shared many occasions with Dr. Hoffman and was well aware of the deserved respect that he held in the hallways and operating room theaters of the Hospital. On this wonderful spring evening, while listening to one of Dr. Humprey's expertly presented tales in his backyard, Dr. Hoffman entered through the front door, thus requiring a long walk through the living room and across the back porch. It was not his normal gallant manner of walking that immediately furthered my admiration for him; instead it was the fact that he was carrying his wife, JoAnn, in his arms because of her incapacity stemming from a disabling ailment. From that time forward, I was never to listen or recount a story of Dr. Hoffman without interjecting some element of his enormous humanity and caring.

I will bookmark this article with many of my other favorites that define the practice and character of pediatric neurosurgery. This history offers the reader who has never visited Sick Kids a great insight into a remarkable place and provides the person familiar with the hospital a stimulus for sentimental memories. My many thanks to Jea et al. for their splendid contribution.

Mark M. Souweidane Toronto, Canada

can write this publication comment on a purely objective basis and without a single prejudice. I unabashedly admit that I have never trained at The Hospital of Sick Children in Toronto, nor have I had the opportunity to visit this renowned institution. However, its influence has made a significant impact on me. I dare say the neurosurgical advances which have emanated from Sick Kids have reached nearly every neurosurgeon who has operated upon a child. So what is the magic of this place? It appears it is a very simple concoction of the following principals: altruism, fortitude, dedication, talent, wise resource management, effective regionalization, internationalism, and formidable but benevolent leadership. More specifically, a group of altruistic women in Toronto had the vision and fortitude to set up a Children's Hospital to serve the children of Canada at a time when none existed. They found ambitious, talented faculty to move their respective practices and dedicate their lives to this vision. The effective political and medical leaders wisely decided to regionalize pediatric care and preserve their precious resources, thus creating a unique regional referral system that attracted the brightest and most gifted surgeons to serve an enormous population of children in need. This atmosphere made the chances for discovery and innovation that much more likely. International colleagues and ideas were imported and generously welcomed to ensure that there was a steady export of ideas, good will, and Sick Kids' selfless culture. The institution retained the native, creative, and colorful surgeons by wisely providing them with cutting edge resources and robust leadership that was renewed from a deep pool of rising stars every 10 years. The authors are to be congratulated for recounting a compelling model of neurosurgical success that has benefited patients worldwide, and is worthy of emulation.

Richard G. Ellenbogen Seattle, Washington

Einstein said, "If I have seen a little farther than others it is because I Chave stood on the shoulders of giants." Pediatric neurosurgery is a recent enough specialty that many of us now in practice have had the privilege of knowing and learning from the founding giants of our field. Bruce Hendricks, Harold Hoffman, and Robin Humphreys of the " $3 \mathrm{H}^{\prime}$ era are among these. Although they have moved from the scene, they live on in what they have passed on to others. The great medical institutions such as Toronto Sick Kids have encouraged and fostered the creativity of such individuals.

Leslie N. Sutton Philadelphia, Pennsylvania 
W riting the history of the Department of Pediatric Neurosurgery at the Sick Children's Hospital in Toronto is somehow writing the history of pediatric neurosurgery. After the pioneering years of Dr. Keith, the impressive influence that Bruce Hendricks had over his generation of colleagues is still remembered today. I first met Harold Hoffman at the International Society for Pediatric Neurosurgery meeting in Rome in 1988, during my second year of residency. It was my first international meeting of neurosurgery, and I remained fascinated by the continuous, vivid, and endless discussions between Drs. Hoffman, Epstein, Schut, Hirsch, and Lapras during the sessions. It was impossible not to note Harold Hoffman, always in the first or second row, apparently not paying too much attention to the speaker but ready to stare at him and let the eyeglass fall whenever he heard something he disagreed with, filling his comments with humor and intelligence. He was part of a generation of neurosurgeons who had to struggle to find a place and identity for pediatric neurosurgery in the larger and more powerful world of general neurosurgery, and he did this very well with personality and intelligence, and even fighting when necessary.

The staff at Sick Kids is a tremendous blend of gentlemen, scientists, and surgeons, each one well aware of the high reputation of the institution and of the scientific group they represent. They are all commit- ted to excellence in order to produce scientific work that will be considered a scientific standard in that specific field around the world. The Shunt Design Trial, designed and completed in the 1990s was a very important turning point for both Sick Kids and the whole community of pediatric neurosurgeons and was a wonderful and enriching experience for all participants. That work has set the standard for much future clinical research, not only in the field of pediatric hydrocephalus but for all of pediatric neurosurgery.

The long tradition and the recent work on hydrocephalus, epilepsy surgery, brain tumor biology, and outcome evaluation are there to witness the commitment of a very productive and dedicated group. For all those who had the pleasure of meeting the staff of Sick Kids, the quality appreciated most remains their ease and kindness in any circumstance, as well as the value they place on friendship and personal relationships, which they keep preciously separated from the scientific and academic process. This article reflects this style very nicely and is certainly very useful for future generations as an example of how an academic, surgical, and scientific group should be.

Giuseppe Cinalli Naples, Italy

\section{INTERNATIONAL TRAVELING FELLOWSHIP in Pediatric Neurosurgery}

$T^{\text {hes }}$ he Joint Pediatric Neurosurgery Section of the American Association of Neurological Surgeons and the Congress of Neurological Surgeons has established an international traveling fellowship for neurosurgeons who at the time of their application are either training in a residency program outside the United States and Canada, or who have completed residency training outside the United States and Canada within the past five years. The fellowship will cover the traveling and living expenses for a three month period to be spent observing the activities of an established Pediatric Neurosurgical service in the United States or Canada. The fellowship can be spent in any activity on such a service which broadens the individual's exposure to Pediatric Neurosurgery, and can include observation at a clinical or research center, or any other relevant activity which the committee finds acceptable. One fellowship per year will be awarded on the basis of the recommendation of a committee of the Pediatric Section. The maximum fellowship stipend is $\$ 5000$.

The application must include:

1) A statement defining the purpose of the proposed fellowship and an estimate of expenses for the period of the fellowship.

2) A letter of recommendation from the applicant's current Neurosurgical program director.

3) A letter of acceptance from the institution where the applicant will seek the fellowship confirming the description of the fellow's activities during the period of the award.

4) The applicant's current Curriculum Vitae.

The completed application should be sent to:

R. Michael Scott, M.D.

Department of Neurosurgery, The Children's Hospital

300 Longwood Avenue, Bader 319

Boston, Massachusetts 02115

or via e-mail to:

michael.scott@childrens.harvard.edu

The Absolute DeAdline fOR ApPliCATION SubMission is NOVEMber 15, 2007 